Aulo Gelio y el análisis

semántico de posibilidades

\title{
Aulus Gellius and the semantic analysis of possibilities
}

Miguel López-Astorga

Universidad de Talca, Chile milopez@utalca.cl

DOI: http://dx.doi.org/10.15366/bp2018.18.021

Bajo Palabra. II Época. No18. Pgs: 407-420

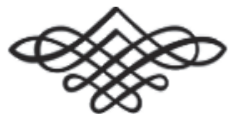


Recibido: 20/06/2016

Aprobado: 29/07/2018

\begin{abstract}
The mental models theory claims that human thought is mainly semantic and consists of analyses of the possibilities that the sentences refer to. The theory has a great empirical support. However, it can be thought that, if it actually shows how the human mind works, it should be possible to find ancient texts authored by philosophers or logicians whose arguments reveal identifications and comparison of semantic possibilities. In this paper, I try to argue that, indeed, texts of that kind are to be found in the ancient sources. In particular, I comment on a fragment written by $\mathrm{Au}-$ lus Gellius in which an analysis of possibilities is clear.
\end{abstract}

Keywords: ancient philosophy, mental models, possibilities, reasoning, semantics.

\section{Resumen}

La teoría de los modelos mentales establece que el pensamiento humano es principalmente semántico y que consiste en análisis de las posibilidades a las que las sentencias hacen referencia. La teoría tiene un gran apoyo empírico. No obstante, se puede pensar que, si realmente muestra cómo la mente humana opera, debería ser posible hallar textos antiguos escritos por filósofos o lógicos cuyos argumentos revelen identificaciones y comparaciones de posibilidades semánticas. En este trabajo, trato de argumentar que, efectivamente, se pueden encontrar textos de este tipo en las fuentes antiguas. En concreto, comento un fragmento de Aulo Gelio en el que está claro que se realiza un análisis de posibilidades.

Palabras clave: modelos mentales, posibilidades, razonamiento, semántica. 


\section{Introduction}

The mental models theORY IS A Very important framework at present. The literature on it is really extensive, and just some relevant works supporting it are, for example, Byrne and Johnson-Laird (2009), Johnson-Laird (2004, 2006, 2010, 2012, 2015), Johnson-Laird and Byrne (2002), Khemlani, Lotstein, Trafton, and Johnson-Laird (2015), Khemlani, Orenes, and Johnson-Laird (2012, 2014), Oakhill and Garnham (1996), Orenes and Johnson-Laird (2012), Quelhas and Johnson-Laird (2017), and Quelhas, Rasga, and Johnson-Laird (2017). Likewise, the theory has been described and commented on in several papers (e.g., López-Astorga, 2015a, 2016). Based on those works and papers, it can be said that one of its fundamental features is that it proposes that the analysis of semantic possibilities, which are also called 'models' by its proponents, is the basic mental process of human reasoning. In this way, the mental models theory rejects the idea that individuals identify the logical forms of the sentences and apply to them formal or syntactic rules.

The truth is that empirical evidence seems to confirm the essential theses of the mental models theory, since most of the experimental results achieved by using logical reasoning tasks are consistent with its predictions and basic assumptions. Nevertheless, one might think that other additional supports could be possible. For example, the evidence in favor of the theory would increase if we found ancient passages or fragments showing that the writer makes a real analysis of semantic possibilities when he exposes his arguments. I think that at least a fragment of that kind exists. That is the one of Aulus Gellius at Noctes Atticae 16, 8, 12-14, which corresponds to passage 9.14 in Boeri and Salles (2014; Spanish version in pp. 218219 , and Latin version in p. 233). In this way, the main aim of this paper is to argue that what is presented in that fragment is actually a true analysis and comparison of combinations of semantic models, i.e., a mental process matching the characteristics that the mental models theory attributes to the natural inferential activity when made by naïve individuals, that is, by individuals without logical training.

To do that, I will begin by a description of the general theses of the mental models theory, which will be the first section of this paper. Then, as a second and final section, I will review the passage cited above in details in order to make it explicit that Gellius' argumentation is really an identification of and a reflection on the se- 
mantic possibilities linked to the sentences that he uses as examples. So, I start with my commentaries on the mental models theory.

\section{The analysis of semantic possibilities provided by the mental models theory}

Maybe it is important to Remind that the MENTAL MOdels theory is not a philosophical or logical theory, but a psychological reasoning theory. However, as acknowledged by Johnson-Laird (2012, p. 135), it has evident philosophical roots, which can be traced back to Peirce (1931-1958). As indicated, the main idea of the theory is that human reasoning is basically semantic. When they make inferences, individuals build mental models, i.e., iconic semantic representations of all the possible scenarios to which sentences refer. Thus, logical form plays no role in human reasoning, which is essentially based on semantic contents.

The theory attributes different possibilities to each traditional operator of logic (conjunction, disjunction, conditional, and biconditional), but, as far as the aims of this paper are concerned, to think about only some cases can be enough. For example, the 'Fully Explicit Models' of a conditional such as 'If A, then B' are as follows (Johnson-Laird, 2012, p. 138, Table 9.2):

\begin{tabular}{c|c|c}
{$[\mathrm{I}]$} & $\mathrm{A}$ & $\mathrm{B}$ \\
\hline$[\mathrm{II}]$ & not-A & $\mathrm{B}$ \\
\hline$[\mathrm{III}]$ & not-A & not-B
\end{tabular}

The first model [I] represents a situation in which both the first clause (A) and the second clause (B) are true. On the other hand, the second model [II] describes a scenario in which the first clause is false and the second one is true. Finally, the third model [III] stands for a situation in which both of them are false. According to the mental models theory, people do not always note all of the Fully Explicit Models. In the particular case of the conditional, only [I], i.e., the one in which both $A$ and $B$ are true, is easy to detect. The other two models require further effort. But, apart from that, another important concept of this theory is the one of 'modulation'. Modulation refers to the fact that some models can sometimes be blocked because of semantics, meanings, or pragmatic factors. A good example of this fact is the following conditional:

"If there is gravity (which there is), then your apples may fall" (Johnson-Laird \& Byrne, 2002, p. 663). 
Conditionals such as this one are interesting because they do not allow applying certain logical rules related to the conditional. That is the case of, for example, Modus Ponendo Ponens, one of the indemonstrables attributed to Chrysippus of Soli by Diogenes Laërtius at Vitae Philosophorum 7, 80. As it is well known, the schema of this indemonstrable is this one:

\author{
If $\mathrm{A}$, then $\mathrm{B}$
}

A

Ergo B

Following the mental models theory, this is an usually valid and correct schema, since, if we pay attention to the models [I], [II], and [III], we can note that the second premise (A) removes [II] and [III] (i.e., the models in which A is false). Thus, the remaining model [I] shows that, if, as stated by the second premise, A is true, it is only possible that $\mathrm{B}$ is true too.

Nevertheless, the case of the example referring to gravity and the apples is problematic because the models of the first premise are not exactly [I], [II], and [III]. Given that it is not possible that there is not gravity, there are only these two possibilities:

\begin{tabular}{c|c} 
Gravity & Your apples fall \\
\hline Gravity & Your apples do not fall
\end{tabular}

The first case is equivalent to [I]. But neither [II] nor [III] represents the second case. This last case refers to a new model:

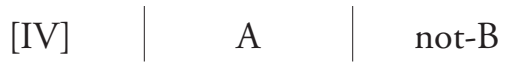

Therefore, the models of the first premise are now [I] and [IV], and Modus Ponendo Ponens cannot be applied because both models are compatible with the second premise (A). So this means that, given A, B can be both true and false.

According to the proponents of the mental models theory, this is a proof that standard logic cannot explain human reasoning and that their approach can do that. Since the first premise in the previous example is a conditional, following standard logic, it should be possible to apply Modus Ponendo Ponens. Nonetheless, 
individuals are not likely to use it in cases such as the one of that example, and only the mental models theory seems to be able to explain this fact.

But the theory can also explain (and predict) other curious cognitive phenomena. According to standard logic, this inference is valid:

$$
\begin{aligned}
& \text { B } \\
& \text { Ergo either A or B }
\end{aligned}
$$

However, people rarely make inferences such as this one, and the mental models theory can explain why. The Fully Explicit Models of an inclusive disjunction are:

\begin{tabular}{c|c|c}
{$[\mathrm{I}]$} & $\mathrm{A}$ & $\mathrm{B}$ \\
\hline$[\mathrm{II}]$ & not-A & $\mathrm{B}$ \\
\hline$[\mathrm{IV}]$ & $\mathrm{A}$ & not-B
\end{tabular}

The problem is that the conclusion enables a possibility in which the premise is false, i.e., the model [II], and this is the reason why individuals tend to reject inferences of this kind. Orenes and Johnson-Laird (2012) tried to prove that this hypothesis is correct and carried out an experiment with tasks such as the following:

"Ana read a novel. Does it follow that Ana read Don Quixote or she read a novel?” (Orenes \& Johnson-Laird, 2012, p. 375).

According to Orenes and Johnson-Laird (2012), individuals should accept the conclusion because the problematic model was not possible in this case. Indeed, the possible situations corresponding to the conclusion of the last task are only:

\begin{tabular}{l|l} 
Ana read Don Quixote & Ana read a novel \\
\hline Ana did not read Don Quixote & Ana read a novel
\end{tabular}

As it can be noted, [I] corresponds to the first situation and [II] corresponds to the second one. [IV] is not possible because it is not possible to read Don Quixote and not to read a novel. Therefore, given that the problematic model is removed by modulation in tasks such as this one, the prediction of the mental models theory is that, in these cases, individuals will not respond as usual and accept the conclusion.

Orenes and Johnson-Laird's (2012) experimental results demonstrated that that prediction was right, since most of their participants responded that the conclusion 
followed. But what is relevant for the goals of this paper is to note that syntax and forms are not important for the mental models theory. In principle, the logical operators have certain models, but, because of modulation, those models are not guaranteed, which means that the presence of terms such as 'if... then...' or 'either... or...' does not rule the conclusions of inferences. I have shown only two examples of how the theory works, one of them related to the conditional and the other one related to the disjunction. Of course, many more examples are to be found in the literature on the mental models theory, but I think that the two described here are illustrative enough and clearly explain the role that semantics plays in the theory.

In this way, the point is that, as said, I propose that Aulus Gellius' fragment mentioned above clearly shows an analysis of possibilities akin to those described in this section. So, I hold that that fragment is one more proof that the mental models theory really accounts for the way human beings actually reason. Obviously, I am not claiming that Gellius' text refers to ideas similar to those of the mental models theory or that anticipations of this last theory are to be found in ancient sources. My only thesis is that the arguments given by Aulus Gellius reveal that his explanation is based on a consideration of semantic possibilities and that, therefore, they are an important support to the hypothesis that people truly reason how the mental models theory states. I argue in favor of this thesis in the next section.

\section{Aulus Gellius, disjunctions, and mental models}

As Indicated, the passage is in Noctes Atticae 16, 8, 12-14, and something important about it is that it explains how the Stoics understood disjunction. Really, the fragment does not reveal a new or unknown thesis of Stoic logic. It only shows the particular way disjunction was considered in that logic, a way that is very different from the interpretation provided by Gentzen's $(1934,1935)$ calculus or standard propositional logic. But all of this has been studied extensively and is well known. As indicated by O’Toole and Jennings (2004, pp. 499-500), Aulus Gellius' passage is not the only ancient fragment accounting for the sense of the Stoic disjunction. For example, Cicero (Topica 14, 56-57), Galen (Institutio Logica 5, 1), or Sextus Empiricus (Pyrrhoniae Hypotyposes 2, 191) do that too. And, as also shown by O'Toole and Jennings (2004, pp. 498-499), several contemporary authors have dealt with the issue as well, e.g., Bocheński (1963, p. 91), Lukasiewicz (1967, p. 74), or Muller (1978, p. 16). Furthermore, other interesting arguments in this regard can be those given by López-Astorga (2015b) or Barnes, Bobzien, and Mignucci (2008, pp. 109-111), and maybe it can also be mentioned that there are even 
studies such as that of López-Astorga (2016) in which the real meaning of Stoic disjunction is explored resorting to the mental models theory too.

So, what is relevant about Gellius' fragment for this paper is not the theses held in it, but only the way those theses are explained in it. That said, I can begin indicating that Gellius is proposing that a correct disjunction $(\delta\llcorner\varepsilon \zeta \varepsilon \cup \gamma \mu \varepsilon \dot{v o v} \alpha \dot{\xi} \xi \omega \mu \alpha$ or disiunctum) has to be essentially exclusive. His example of a good disjunction is this one:

'aut malum est voluptas, aut bonum aut neque bonum neque malum est' ('either pleasure is bad or good, or neither good nor bad'; see also, both for this sentence and other sentences in the passage commented on below, e.g., the translations in López-Astorga, 2016, p. 236, which is very similar but not exactly the same as mine here).

Besides, unlike exclusive disjunction in standard logic, a disjunction such as the previous one can only be correct if just one of its disjuncts is true. According to Gellius, the disjuncts must be inconsistent with each other, and the opposites (op-

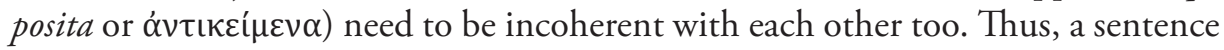
that appears to be a disjunction is not so if one or more of these circumstances happen:

-No disjunct is true.

-More than one disjunct is true.

-The disjuncts are not inconsistent with each other.

-The opposites of the disjuncts are not inconsistent with each other.

In these cases, the appropriate name for the sentence is $\pi \alpha \rho \alpha \delta\llcorner\varepsilon \zeta \varepsilon \cup \gamma \mu \varepsilon \dot{v o v}$, and Aulus Gellius also gives an example of this kind of sentence:

'aut curris aut ambulas aut stas' ('either you run, or you walk, or you are immobile')

The problem with this example is that the opposites are not contradictory. Indeed, although the disjuncts are inconsistent with each other, the opposites are not, since it is possible not to walk, not to be immobile, and not to run at the same time.

Beyond the obvious differences that, following Gellius' description, can be found between the Stoic disjunction and that of standard logic, which, as said, have been reviewed in details in sources and works such as those mentioned, the fragment reveals a real underlying analysis of possibilities. Given an expression with three propositions such as those used in Gellius' passage, in principle, all of the possible combinations would be these ones: 


\begin{tabular}{c|c|c|c}
{$[\mathrm{V}]$} & $\mathrm{A}$ & $\mathrm{B}$ & $\mathrm{C}$ \\
\hline$[\mathrm{VI}]$ & $\mathrm{A}$ & $\mathrm{B}$ & not-C \\
\hline$[\mathrm{VII}]$ & $\mathrm{A}$ & not-B & $\mathrm{C}$ \\
\hline$[\mathrm{VIII}]$ & $\mathrm{A}$ & not-B & not-C \\
\hline$[\mathrm{IX}]$ & not-A & $\mathrm{B}$ & $\mathrm{C}$ \\
\hline$[\mathrm{X}]$ & not-A & $\mathrm{B}$ & not-C \\
\hline$[\mathrm{XI}]$ & not-A & not-B & $\mathrm{C}$ \\
\hline$[\mathrm{XII}]$ & not-A & not-B & not-C
\end{tabular}

Nevertheless, because the text says that 'ex omnibus, quae disiunguntur, unum esse verum debet, falsa cetera' ('only one of all of the disjuncts should be true, and the others should be false'), the possibilities in which more than one disjunct is true (i.e., the possibilities [V], [VI], [VII], and [IX]) must be removed. However, the passage adds that if 'nihil omnium verum' ('no disjunct is true'), then that is not a disjunction. So, it is also necessary to eliminate the combination [XII], since all of the disjuncts are false in it. Therefore, only three combinations remain: [VIII], [X], and [XI], and, according to Gellius, those would be the correct combinations for the disjunction.

Nonetheless, that he is doing an analysis of possibilities appears to be even more obvious if we pay attention to his example of incorrect disjunction. He claims that the problem with that example is that, although 'nam ipsa quidem inter se adversa sunt' ('they are inconsistent with each other'), 'opposita eorum non pugnant' (their opposites are not in conflict). And this means that the possibilities corresponding to that example are as follows:

\begin{tabular}{c|c|c} 
To walk & Not to be immobile & Not to run \\
\hline Not to walk & To be immobile & Not to run \\
\hline Not to walk & Not to be immobile & To run \\
\hline Not to walk & Not to be immobile & Not to run
\end{tabular}

It is clear that the first combination is equivalent to [VIII], the second one to $[\mathrm{X}]$, and the third one to $[\mathrm{XI}]$. The problem is that the fourth combination is also 
possible in the example, and it refers to [XII], a forbidden combination for the disjunction.

So, as it can be noted, Gellius' arguments seem to consist of an analysis of semantic (in the sense that the mental models theory attributes to this word) possibilities or models, since his idea appears to be to show which combinations can be accepted and which combinations must be rejected in the case of disjunction. And this is even clearer if we take into account the fact that the passage reveals that, to Aulus Gellius, the appearance of the word aut (or) is not the fundamental factor. What is really important is the content or meaning of the disjuncts, which, as said, leads one to think in an evident analysis of possibilities.

Of course, this can also lead to conjectures about the true nature of Stoic logic, and to the idea that perhaps this last logic is closer to semantic approaches such as the mental models theory than syntactic frameworks such as that of Gentzen $(1934,1935)$ (in the sense that the words 'semantic' and 'syntactic' have in the contemporary cognitive science). Nevertheless, this paper has not been intended to address this type of discussions (for it, see, e.g., López-Astorga, 2016). Its main aim was to show that we can find evidences that human beings reason in accordance with the way proposed by the mental models theory in texts written in ancient times, and I think that the study of the Gellius' fragment at Noctes Atticae 16, 8, 12-14 made here has enabled to achieve that aim.

\section{Conclusions}

IT IS TRUE THAT THE MENTAL MODELS THEORY is not the only current theory trying to account for how people make inferences. There are other theories too, and one of them that is also very important is, for example, the mental logic theory (e.g., Braine \& O'Brien, 1998; O’Brien, 2009, 2014; O’Brien \& Li, 2013; O’Brien \& Manfrinati, 2010), but the strong empirical support that the former has and the great number of aspects related to cognition that it can explain can lead one to assume that it actually describes the real working of the human reasoning ability.

But, if this last idea is assumed, it can make sense to look for more evidence for the mental models theory in ancient texts. True, it can be thought that, if this theory is correct and really shows how people reason, it must be possible to find evidences of that among the arguments given by philosophers in the course of history. In this way, I have proposed in this paper that there is at least a passage (that of Aulus Gellius reviewed above) coming from ancient times in which such evidences are clear. 
As said, by this I do not mean that Stoic logic and the mental models theory are necessarily related and that there is no doubt that the former somehow anticipated the latter. The context in which Stoic logic was provided and presented is very different from the contemporary context in which the mental models theory has been proposed, and the goals and the problems to solve of these two frameworks hence are not similar. In fact, there are very interesting works (e.g., Bobzien, 1996; or Barnes, Bobzien, \& Mignucci, 2008) that offer very detailed explanations of which the true sense of Stoic logic could be, and, as it can be noted in those works, that sense cannot be easily linked to the basic theses of the mental models theory.

Thus, my only claim is that the way Aulus Gellius exposes certain technical definitions of Stoic logic reveals that he is reasoning how the mental models theory argues, and that, therefore, this can be considered to be an additional support for the theory. And this is so because that fact can lead one to think that the mental models theory actually describes how our mind works. So, it can be said that to continue to analyze ancient texts referring to not only logical but also philosophical issues in order to check whether or not the arguments included in them show reasoning processes such as those held by the mental models theory can be a very relevant task at present. Furthermore, it is obvious that this activity can be fruitful not only if Greek texts are taken into account, but also if texts coming from other cultural traditions, such as, e.g., the Chinese one or the Indian one, are considered. 


\section{REFERENCES}

Barnes, J., Bobzien, S., \& Mignucci, M. (2008). Logic. In K. Algra, J. Barnes, J. Mansfeld, \& M. Schofield (Eds.), The Cambridge History of Hellenistic Philosophy (pp. 77-225). Cambridge, UK: Cambridge University Press.

Bobzien, S. (1996). Stoic syllogistic. In C. C. W. Taylor (Ed.), Oxford Studies in Ancient Philosophy (pp. 133-192). Oxford, UK: Clarendon Press.

Bocheński, I. M. (1963). Ancient Formal Logic. Amsterdam, The Netherlands: North-Holland.

Boeri, M. D. \& Salles, R. (2014). Los filósofos estoicos. Ontología, lógica, física y ética. Santiago de Chile, Chile: Ediciones Universidad Alberto Hurtado.

Braine, M. D. S. \& O’Brien, D. P. (Eds.) (1998). Mental Logic. Mahwah, NJ: Lawrence Erlbaum Associates, Inc., Publishers.

Byrne, R. M. J. \& Johnson-Laird, P. N. (2009). "If" and the problems of conditional reasoning. Trends in Cognitive Science, 13(7), 282-287.

Gentzen, G. (1934). Untersuchungen über das logische Schließen I. Mathematische Zeitschrift, 39(2), 176-210.

- (1935). Untersuchungen über das logische Schließen II. Mathematische Zeitschrift, 39(3), 405-431.

Johnson-Laird, P. N. (2004). The history of the mental models. In K. Manktelow \& M. C. Chung (Eds.), Psychology and Reasoning: Theoretical and Historical Perspectives (pp. 179-212). New York, NY: Psychology Press.

- (2006). How We Reason. Oxford, UK: Oxford University Press.

- (2010). Against logical form. Psychologica Belgica, 5(3/4), 193-221.

- (2012). Inference with mental models. In K. J. Holyoak \& R. G. Morrison (Eds.), The Oxford Handbook of Thinking and Reasoning (pp. 134-145). New York, NY: Oxford University Press.

- (2015). How to improve thinking. In R. Wegerif, L. Li, \& J. C. Kaufman (Eds.), The Routledge International Handbook of Research on Teaching Thinking (pp. 80-91). Abingdon, UK, \& New York, NY: Routledge.

Johnson-Laird, P. N. \& Byrne, R. M. J. (2002). Conditionals: A theory of meaning, pragmatics, and inference. Psychological Review, 109(4), 646-678. 
Khemlani, S., Lotstein, M., Trafton, J. G., \& Johnson-Laird, P. N. (2015). Immediate inferences from quantified assertions. The Quarterly Journal of Experimental Psychology, 68(10), 2073-2096.

Khemlani, S., Orenes, I., \& Johnson-Laird, P. N. (2012). Negation: A theory of its meaning, representation, and inference. Psychological Review, 109(4), 646678.

- (2014). The negation of conjunctions, conditionals, and disjunctions. Acta Psychologica, 151, 1-7.

López-Astorga, M. (2015a). Evolved mechanisms versus underlying conditional relations. Studies in Logic, Grammar and Rhetoric, 40(53), 241-253.

- (2015b). Chrysippus' indemonstrables and mental logic. Croatian Journal of Philosophy, 15(43), 1-15.

- (2016). The problem of arity in Stoic logic: The case of the disjunction. Thémata. Revista de Filosofia, 54, 233-246

Lukasiewicz, J. (1967). On the history of the logic of propositions. In S. McCall (Ed.), Polish Logic: 1920-1939 (pp. 67-87). Oxford, UK: Clarendon Press.

Mueller, I. (1978). An introduction to Stoic logic. In J. M. Rist (Ed.), The Stoics (pp. 1-26). Berkeley, CA: University of California Press.

Oakhill, J. \& Garnham, A. (Eds.) (1996). Mental Models in Cognitive Science. Essays in Honour of Phil Johnson-Laird. Hove, UK: Psychology Press.

O’Brien, D. P. (2009). Human reasoning includes a mental logic. Behavioral and Brain Sciences, 32, 96-97.

- (2014). Conditionals and disjunctions in mental-logic theory: A response to Liu and Chou (2012) and to López-Astorga (2013). Universum, 29(2), 221-235.

O’Brien, D. P. \& LI, S. (2013). Mental logic theory: A paradigmatic case of empirical research on the language of thought and inferential role semantics. Journal of Foreign Languages, 36(6), 27-41.

O’Brien, D. P. \& Manfrinati, A. (2010). The mental logic theory of conditional proposition. In M. Oaksford \& N. Chater (Eds.), Cognition and conditionals: Probability and Logic in Human Thinking (pp. 39-54). Oxford, UK: Oxford University Press.

Orenes, I. \& Johnson-Laird, P. N. (2012). Logic, models, and paradoxical inferences. Mind \& Language, 27(4), 357-377. 
O’Toole, R. R. \& Jennings, R. E. (2004). The Megarians and the Stoics. In M. D. Gabbay \& J. Woods (Eds.), Handbook of the History of Logic, Volume I. Greek, Indian and Arabic Logic (pp. 397-522). Amsterdam, The Netherlands: Elsevier.

Peirce, C. S. (1931-1958). Collected papers of Charles Sanders Peirce. C. Hartshorne, P. Weiss, \& A. Burks (Eds.). Cambridge, MA: Harvard University Press.

Quelhas, A. C. \& Johnson-Laird, P. N. (2017). The modulation of disjunctive assertions. The Quarterly Journal of Experimental Psychology, 70(4), 703-717.

Quelhas, A. C., Rasga, C., \& Johnson-Laird, P. N. (2017). A priori true and false conditionals. Cognitive Science, 41(55), 1003-1030.

DOI: http://dx.doi.org/10.15366/bp2018.18.021

Bajo Palabra. II Época. No18. Pgs: 407-420 